GAMBARAN TINGKAT PENGETAHUAN, SIKAP DAN TINDAKAN PASIEN TUBERKULOSIS TERHADAP KEJADIAN TB PARU DI PUSKESMAS MEDAN AREA SELATAN

JURNAL KESEHATAN

http://ejournal.poltekkesternate.ac.id/ojs

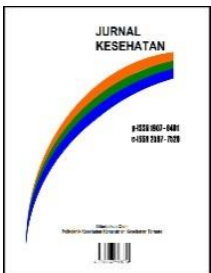

\title{
GAMBARAN TINGKAT PENGETAHUAN, SIKAP DAN TINDAKAN PASIEN TUBERKULOSIS TERHADAP KEJADIAN TB PARU DI PUSKESMAS MEDAN AREA SELATAN
}

\author{
Rizky Amelia Hasibun ${ }^{1 凶}$, Nurul Hidayah ${ }^{2}$. \\ ${ }^{1}$ Poltekkes Kemenkes Medan, Indonesia \\ 1nurul.hidayah3607@gmail.com
}

\begin{tabular}{l}
\hline Info Artikel \\
\hline Sejarah Artikel: \\
Diterima Februari 2017 \\
Disetujui April 2017 \\
Di Publikasi Mei 2017
\end{tabular}

Keywords:

Petunjuk Penulisan ;

Jurnal Kesehatan;

Template Artikel

( Terdiri dari 3-5 kata )

\begin{abstract}
Abstrak
Tuberkulosis (TB) paru adalah penyakit menular yang disebabkan oleh Mycobacterium tuberculosis. Sebagian besar kuman TB menyerang paru, tetapi dapat juga mengenai organ tubuh lainnya. Tujuan penelitian ini adalah untuk mengetahui tingkat pengetahuan, sikap, dan tindakan pasien tentang penyakit TB paru. Metode penelitian yang digunakan adalah penelitian deskriptif yang bersifat prospektif dengan memberikan kuesioner kepada pasien TB paru yang berobat di puskesmas Medan Area Selatan. Responden yang dijadikan sampel adalah yang memenuhi kriteria inklusi. Data yang diperoleh selanjutnya dianalisa dengan menghitung distribusi karakteristik responden (jenis kelamin, usia, pendidikan, pekerjaan, penghasilan dan lama menderita TB) serta jawaban kuesioner yang mencakup (pengetahuan, sikap dan tindakan). Hasil dari karakteristik responden yang paling banyak adalah berada pada usia dewasa (76,47\%); laki-laki (82,35\%); pendidikan SMA $(64,71 \%)$; pekerjaan wiraswasta $(64,71 \%)$; lama menderita $\mathrm{TB}<6$ bulan (76,47\%); penghasilan $>$ Rp.1.000.000-Rp.2.000.000 dan tidak berpenghasilan adalah sebesar $35,29 \%$. Hasil penelitian menunjukkan tingkat pengetahuan, sikap, dan tindakan paling banyak berada dalam kategori cukup baik $(64,71 \%)$, baik $(88,24 \%)$, dan baik $(70,59 \%)$ secara berturut-turut. Tingkat pengetahuan yang cukup baik dari pasien TB paru Puskesmas Medan Area Selatan, diimplementasikan dalam sikap dan tindakan dalam kategori baik terhadap penularan, penyebab, pencegahan dan pengobatan TB.
\end{abstract}

Kata Kunci: Pengetahuan, Sikap, Tindakan, Tuberkulosis Paru, Puskesmas

\section{Abstract}

Pulmonary tuberculosis (TB) is an infectious disease caused by Mycobacterium tuberculosis. Most TB germs attack the lungs, but also affect other organs. The purpose of this study was to determine the level of knowledge, attitudes, and actions of patients about pulmonary TB disease. Design of this research was descriptive with prospective methods by providing questionnaires to pulmonary TB patients who were treated at the Puskesmas Medan Area Selatan. Sample were those who met the inclusion criteria. The data were obtained then analyzed by calculating the distribution of respondents characteristics (gender, age, education, occupation, income and duration of suffering from TB) and the answers to the questionnaire which included (knowledge, attitudes and actions). The results of the most characteristic respondents were in the adult age (76.47\%); male (82.35\%); high school education (64.71\%); occupation (64.71\%); duration of TB 
GAMBARAN TINGKAT PENGETAHUAN, SIKAP DAN TINDAKAN PASIEN TUBERKULOSIS TERHADAP KEJADIAN TB PARU DI PUSKESMAS MEDAN AREA SELATAN

$<6$ months (76.47\%); income > Rp.1,000,000-Rp.2,000,000 and no income is $35.29 \%$. The results showed the highest level of knowledge, attitudes, and actions respectively were in passably category $(64.71 \%)$, good $(88.24 \%)$, and good $(70.59 \%)$ respectively. A enough level of knowledge of pulmonary TB patients in Puskesmas Medan Area Selatan is implemented in the form of good attitudes and actions towards the transmission, causes, prevention and treatment of TB.

Keyword: Knowledge, attitudes, action, pulmonary tuberculosis, Puskesmas

2019 Poltekkes Kemenkes Ternate

Alamat korespondensi:

Poltekkes Kemenkes Ternate, Ternate - West Maluku Utara, Indonesia

Email: uppmpoltekkesternate@gmail.co.id

ISSN 2597-7520

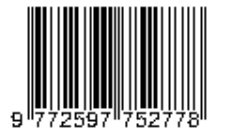




\section{GAMBARAN TINGKAT PENGETAHUAN, SIKAP DAN TINDAKAN PASIEN TUBERKULOSIS TERHADAP KEJADIAN TB PARU DI PUSKESMAS MEDAN AREA SELATAN}

\section{PENDAHULUAN}

Tuberkulosis (TB) paru adalah penyakit menular langsung yang disebabkan oleh kuman TB yaitu Mycobacterium tuberculosis. Sebagian besar kuman TB menyerang paru, tetapi dapat juga mengenai organ tubuh lainnya. Diperkirakan sekitar sepertiga penduduk dunia telah terinfeksi oleh Mycobacterium tuberculosis. Jika tidak diobati, penyakit ini bersifat fatal dalam waktu 5 tahun pada 50-65\% kasus. Penularan biasanya berlangsung melalui percikan dahak (droplet nucleic) di udara yang berasal dari pasien TB paru infeksius (Loscalzo J, 2014).

Secara global pada tahun 2016 terdapat 10,4 juta kasus insiden TB yang setara dengan 120 kasus per 100.000 penduduk. Lima negara dengan insiden kasus tertinggi yaitu India, Indonesia, China, Philipina dan Pakistan (Infodatin, 2018). Pada tahun 2016 ditemukan jumlah kasus TB di Indonesia sebanyak 351.893 kasus, meningkat bila dibandingkan semua kasus TB yang ditemukan pada tahun 2014 yang sebesar 330.729 kasus (Kemenkes RI, 2017). Berdasarkan jumlah penduduk tahun 2014 diperhitungkan sasaran penemuan kasus baru TB paru Basil Tahan Asam (BTA) $(+)$ di Provinsi Sumatera Utara adalah sebesar 22.026 jiwa dan hasil cakupan penemuan kasus baru TB paru BTA $(+)$ yaitu 11.818 kasus atau $76,35 \%$. Angka ini mengalami kenaikan bila dibandingkan dengan cakupan penemuan kasus baru tahun 2013 sebesar 72,29\% (Profil Kesehatan Sumatera Utara, 2014). Pada tahun 2016 penemuan kasus baru TB paru BTA $(+)$ di Kota Medan adalah sebesar 126,89\%, meningkat bila dibandingkan kasus baru TB paru BTA $(+)$ pada tahun 2013 sebesar 122,88\%. Sedangkan pada tahun 2016 jumlah kasus baru TB paru BTA (+) di Medan Area pada jenis kelamin laki-laki sebesar $66 \%$ dan pada jenis kelamin perempuan sebesar 34,29\% (Profil Kesehatan Kota Medan, 2016).

Terdapat beberapa faktor yang mempengaruhi kejadian TB pada kelompok masyarakat diantaranya: faktor predisposis (status gizi, imunisasi, HIV, diabetes melitus dan pendidikan), faktor pendukung (lingkungan rumah, sosial ekonomi, fasilitas dan sarana kesehatan), faktor pendorong (gaya hidup dan perilaku masyarakat) serta lainnya (umur dan jenis kelamin) (Suprapto, 2007).

Tindakan pencegahan yang dapat dilakukan dengan mengobati penderita TB paru secara rutin sesuai jadwal pengobatan. Sulitnya pemberantasan penyakit ini karena dalam pemberantasannya bukan hanya masalah bakteri atau obat-obatan saja, melainkan melengkapi aspek sosial, budaya, ekonomi, tingkat pendidikan, pengetahuan penderita dan keluarga, serta lingkungan masyarakat sekitar (Wahyudi E, 2006).

Menurut penelitian sebelumnya sebanyak 94,9\% responden mengatakan bahwa mereka pernah mendengar tentang TB, hanya $22,9 \%$ yang tahu bahwa TB disebabkan oleh bakteri, $80 \%$ memiliki kesadaran bahwa TB dapat ditularkan dari pasien ke orang lain dan 79,3\% tahu penularan TB dapat dicegah, 71,0\% responden mengatakan bahwa mereka akan mencari perawatan di fasilitas kesehatan jika mereka menyadari bahwa mereka memiliki gejala terkait dengan $\mathrm{TB}, 55,4 \%$ responden menganggap TB sebagai penyakit yang sangat serius dan $69,3 \%$ responden akan mengalami ketakutan jika mereka sendiri menderita TB (Paul et al, 2015). Menurut penelitian terdahulu yang dilakukan di Puskesmas Sidomulyo Kota Pekanbaru pengetahuan pasien TB paru terhadap upaya pengendalian penyakit TB masuk dalam kategori cukup yaitu $51,6 \%$, sedangkan sikap pasien TB paru terhadap pengendalian penyakit TB masuk dalam kategori baik yaitu $87 \%$ dan tindakan pasien TB paru terhadap upaya pengendalian penyakit TB masuk dalam kategori cukup yaitu 38,7\% (Dewita R, 2017). Drop out (penghentian pengobatan sebelum waktunya) Di Indonesia merupakan faktor terbesar dalam kegagalan pengobatan penderita TB yang besarnya $50 \%$. Masalah yang ditimbulkan oleh drop out $\mathrm{OAT}$ adalah resistensi obat sehingga akan menimbulkan proporsi kasus retreatment yang tinggi dimasa yang akan datang (Depkes RI, 2008).

Untuk mengatasi masalah tersebut, harus ditunjang dengan pengetahuan tentang 


\section{GAMBARAN TINGKAT PENGETAHUAN, SIKAP DAN TINDAKAN PASIEN TUBERKULOSIS TERHADAP KEJADIAN TB PARU DI PUSKESMAS MEDAN AREA SELATAN}

penyakit TB paru yang baik. Pengetahuan yang baik akan mempengaruhi sikap dan tindakan pasien untuk bertindak dalam hal pencegahan penularan dan proses kesembuhan penderita. Sebaliknya makin rendah pengetahuan pasien tentang bahaya penyakit TB paru, makin besar pula resiko terjadi penularan dan proses kesembuhan penderita kurang optimal. Berdasarkan uraian di atas dilakukan penelitian untuk mengetahui gambaran pengetahuan, sikap dan tindakan pasien terhadap kejadian TB paru di Puskesmas Medan Area Selatan. Data yang dikumpulkan adalah data primer dengan membagikan kuesioner kepada pasien TB dengan diagnosa TB Paru selama 1 bulan.

\section{METODE PENELITIAN}

Jenis penelitian yang digunakan pada penelitian ini adalah penelitian deskriptif memberikan kuesioner kepada pasien TB paru yang berobat di puskesmas Medan Area Selatan.

\section{Lokasi dan Waktu Penelitian}

Lokasi penelitian di puskesmas Medan Area Selatan yang berada di jalan Medan Area Selatan, Kelurahan Sukaramai I, Kecamatan Medan Area, Kota Medan, Sumatera Utara. Waktu penelitian dilakukan selama tiga bulan di mulai dari bulan April sampai Juni 2019.

\section{Populasi dan Sampel}

Populasi dalam penelitian ini adalah semua pasien yang terdiagnosa TB paru. Berdasarkan survey pendahuluan yang telah dilakukan jumlah pasien TB paru yang berobat di Puskesmas Medan Area Selatan bulan Januari sampai April 2019 adalah 12 pasien.

Sampel dalam penelitian ini adalah yang memenuhi kriteria inklusi. Yang menjadi kriteria inklusi adalah: Pasien dengan diagnosa TB paru; Pasien yang berobat di puskesmas Medan Area Selatan pada periode minggu kedua bulan Mei 2019 sampai minggu kedua bulan Juni 2019; dana Pasien dengan usia dewasa dan lansia.

\section{Variabel Penelitian}

Variabel bebas dalam penelitian ini adalah karakteristik responden (usia, jenis kelamin, pendidikan terakhir, pekerjaan, penghasilan dan lama menderita TB), sedangkan variabel terikat adalah tingkat pengetahuan, sikap dan tindakan responden.

\section{Jenis Data dan Pengumpulan Data}

Jenis data yang diambil pada penelitian ini adalah data primer. Pengumpulan data diperoleh secara langsung dari responden dengan membagikan kuesioner yang telah dipersiapkan oleh peneliti.

\section{Pengolahan dan Analisis Data}

Analisis data dilakukan dengan menghitung jumlah dan persentase dari karakteristik responden (usia, jenis kelamin, pendidikan terakhir, pekerjaan, penghasilan dan lama menderita TB) serta jawaban kuesioner yang mencakup (pengetahuan, sikap dan tindakan). Data yang diperoleh selanjutnya diolah dengan MS. Excel dan disajikan dalam bentuk tabel distribusi frekuensi.

\section{Pengukuran Variabel}

Variabel pengetahuan diukur dengan cara membuat kuesioner dengan 10 pertanyaan, masing-masing dari pertanyaan memiliki jawaban yang berbeda-beda (lihat lampiran 1). Total skor tertinggi pada kuesioner pengetahuan ini adalah 18 .

Variabel sikap diukur dengan skala likert. Skala likert digunakan untuk mengukur sikap, pendapat dan persepsi seseorang atau sekelompok orang tentang fenomena sosial (Sugiyono, 2013). Pertanyaan-pertanyaan yang berhubungan dengan sikap memiliki jawaban yang berbeda-beda yaitu terdiri dari sangat setuju, setuju, tidak setuju dan sangat tidak setuju. Nilai tertinggi tiap satu pertanyaan adalah 4 (empat). Total skor tertinggi adalah 40 .

Variabel tindakan diukur dengan skala Guttman. Nilai tertinggi tiap satu pertanyaan 
GAMBARAN TINGKAT PENGETAHUAN, SIKAP DAN TINDAKAN PASIEN TUBERKULOSIS TERHADAP KEJADIAN TB PARU DI PUSKESMAS MEDAN AREA SELATAN

adalah 1 (satu), jumlah pertanyaan 10 (sepuluh). Maka total skor tertinggi dari seluruh pertanyaan adalah 10 . Pertanyaanpertanyaan yang berhubungan dengan tindakan memiliki jawaban dengan dua pilihan Ya dan Tidak.

Berdasarkan total skor yang diperoleh pengetahuan dibagi menjadi empat tingkatan yaitu:

a. $76-100 \%$ jawaban benar : Baik

b. $56-75 \%$ jawaban benar : Cukup baik

c. $40-55 \%$ jawaban benar : Kurang baik

d. $<40 \%$ jawaban benar: Tidak baik

\section{HASIL DAN PEMBAHASAN}

\section{Karakteristik Responden}

Pada survey awal didapatkan semua suspek TB paru selama bulan Januari-April sebanyak 48 pasien tetapi sampel atau responden yang memenuhi kriteria inklusi adalah sebanyak 17 pasien. Karakterisktik responden yang diperoleh dikelompokkkan berdasarkan usia, jenis kelamin, pendidikan terakhir, pekerjaan, penghasilan dan lama menderita TB paru. Berdasarkan Tabel 1 karakteristik responden yang paling banyak adalah berada pada usia dewasa (76,47\%); laki-laki (82,35\%); tingkat pendidikan SMA $(64,71 \%)$; pekerjaan wiraswasta $(64,71 \%)$; lama menderita $\mathrm{TB}<6$ bulan $(76,47 \%)$; penghasilan $>$ Rp.1.000.000Rp.2.000.000 dan tidak berpenghasilan adalah sebesar $35,29 \%$. 
GAMBARAN TINGKAT PENGETAHUAN, SIKAP DAN TINDAKAN PASIEN TUBERKULOSIS TERHADAP KEJADIAN TB PARU DI PUSKESMAS MEDAN AREA SELATAN

Tabel 1. Distribusi frekuensi karakteristik responden

\begin{tabular}{|c|c|c|}
\hline Karakteristik Responden & Jumlah & Persentase \\
\hline \multicolumn{3}{|l|}{ Usia } \\
\hline$\geq 18-65$ (Dewasa) & 13 & 76,47 \\
\hline$\geq 65($ Lansia $)$ & 4 & 23,53 \\
\hline \multicolumn{3}{|l|}{ Jenis Kelamin } \\
\hline Laki-laki & 14 & 82,35 \\
\hline Perempuan & 3 & 17,65 \\
\hline \multicolumn{3}{|l|}{ Pendidikan Terakhir } \\
\hline Tidak Tamat SD/Tamat SD & 5 & 29,41 \\
\hline Tamat SMP & 1 & 5,88 \\
\hline Tamat SMA & 11 & 64,71 \\
\hline Tamat Akademi/Sarjana & 0 & 0,00 \\
\hline \multicolumn{3}{|l|}{ Pekerjaan } \\
\hline Tidak Bekerja/Ibu Rumah Tangga & 6 & 35,29 \\
\hline Wiraswasta & 11 & 64,71 \\
\hline Pegawai Negeri Sipil & 0 & 0,00 \\
\hline Lain-Lain & 0 & 0,00 \\
\hline \multicolumn{3}{|l|}{ Penghasilan } \\
\hline$<$ Rp. 1.000 .000 & 5 & 29,41 \\
\hline$>$ Rp.1.000.000-Rp.2.000.000 & 6 & 35,29 \\
\hline$>$ Rp.2.000.000-Rp.3.500.000 & 0 & 0,00 \\
\hline$>$ Rp.3.500.000-Rp.5.000.000 & 0 & 0,00 \\
\hline$>$ Rp.5.000.000 & 0 & 0,00 \\
\hline Tidak Berpenghasilan & 6 & 35,29 \\
\hline \multicolumn{3}{|l|}{ Lama Menderita TB Paru } \\
\hline$<6$ Bulan & 13 & 76,47 \\
\hline$>6$ Bulan & 4 & 23,53 \\
\hline
\end{tabular}

\section{Distribusi Pengetahuan, Sikap dan Tindakan Responden}

Distribusi pengetahuan, sikap dan tindakan responden dikelompokkan berdasarkan yaitu usia, jenis kelamin, pendidikan terakhir, pekerjaan, penghasilan dan lama menderita TB. Berdasarkan hasil penelitian dengan menggunakan kuesioner diperoleh data bahwa responden yang mempunyai pengetahuan cukup baik sebanyak 11 responden, kurang baik sebanyak 3 responden dan tidak baik sebanyak 3 responden; sedangkan responden yang memiliki sikap baik sebanyak 15 responden dan cukup baik sebanyak 2 responden dan untuk tindakan diperoleh sebanyak 12 responden menunjukkan tindakan baik dan 5 responden menunjukkan tindakan yang cukup baik.

Berdasarkan Gambar 1 diketahui bahwa pengetahuan, sikap, dan tindakan responden pada usia dewasa yang paling banyak secara berturut-turut adalah kategori cukup baik sebesar 47,06\% untuk pengetahuan; sikap dengan kategori baik sebesar 64,71\%, dan tindakan dengan kategori baik sebesar $58,82 \%$.

Berdasarkan Gambar 2 diketahui bahwa pengetahuan, sikap, dan tindakan responden pada jenis kelamin laki-laki yang paling banyak secara berturut-turut 
GAMBARAN TINGKAT PENGETAHUAN, SIKAP DAN TINDAKAN PASIEN TUBERKULOSIS TERHADAP KEJADIAN TB PARU DI PUSKESMAS MEDAN AREA SELATAN

adalah kategori cukup baik sebesar $58,82 \%$ untuk pengetahuan; sikap dengan kategori baik sebesar 70,59\%, dan tindakan dengan kategori baik sebesar $64,71 \%$. 
GAMBARAN TINGKAT PENGETAHUAN, SIKAP DAN TINDAKAN PASIEN TUBERKULOSIS TERHADAP KEJADIAN TB PARU DI PUSKESMAS MEDAN AREA SELATAN

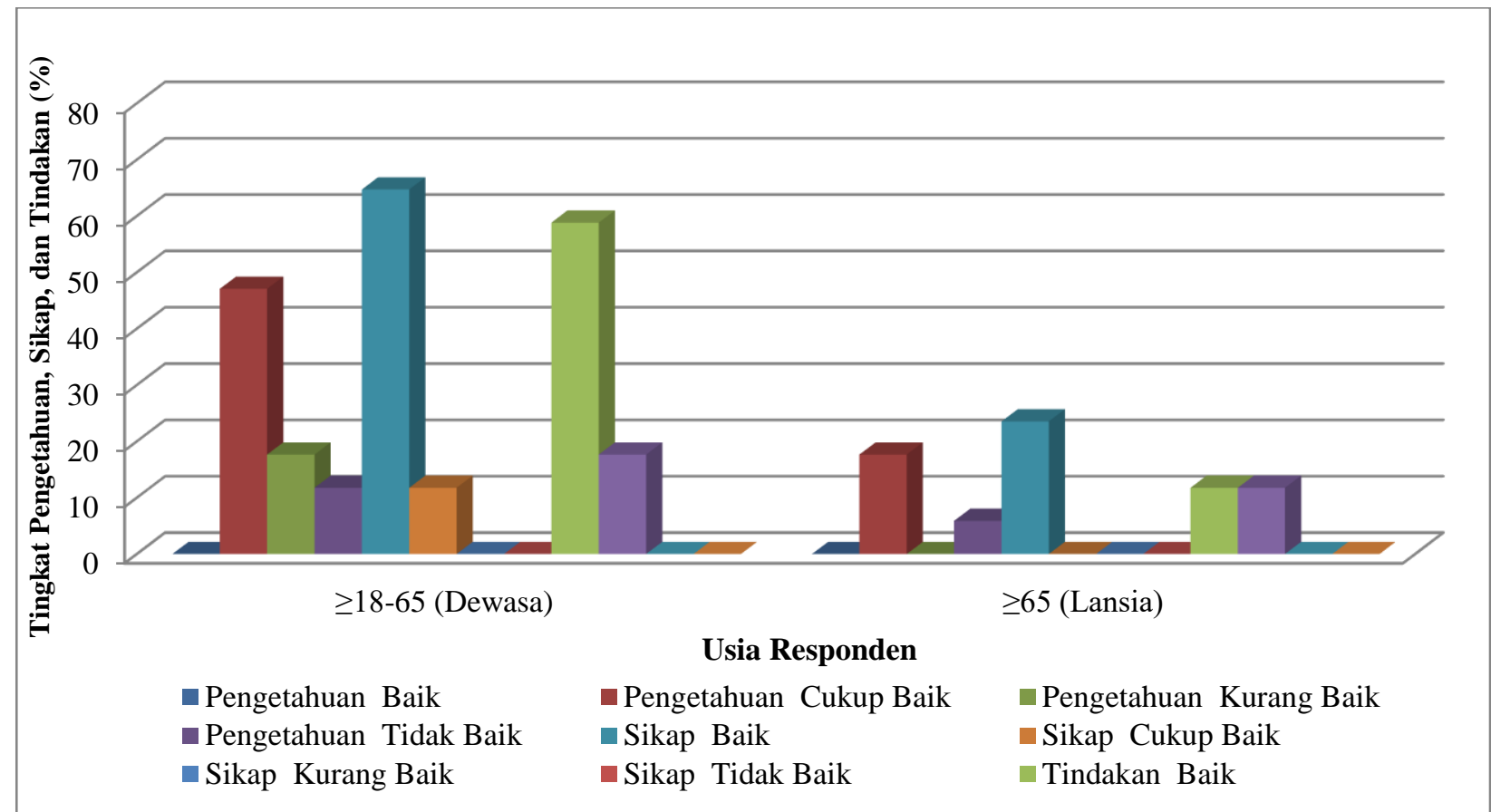

Gambar 1. Grafik persentase pengetahuan, sikap dan tindakan berdasarkan usia

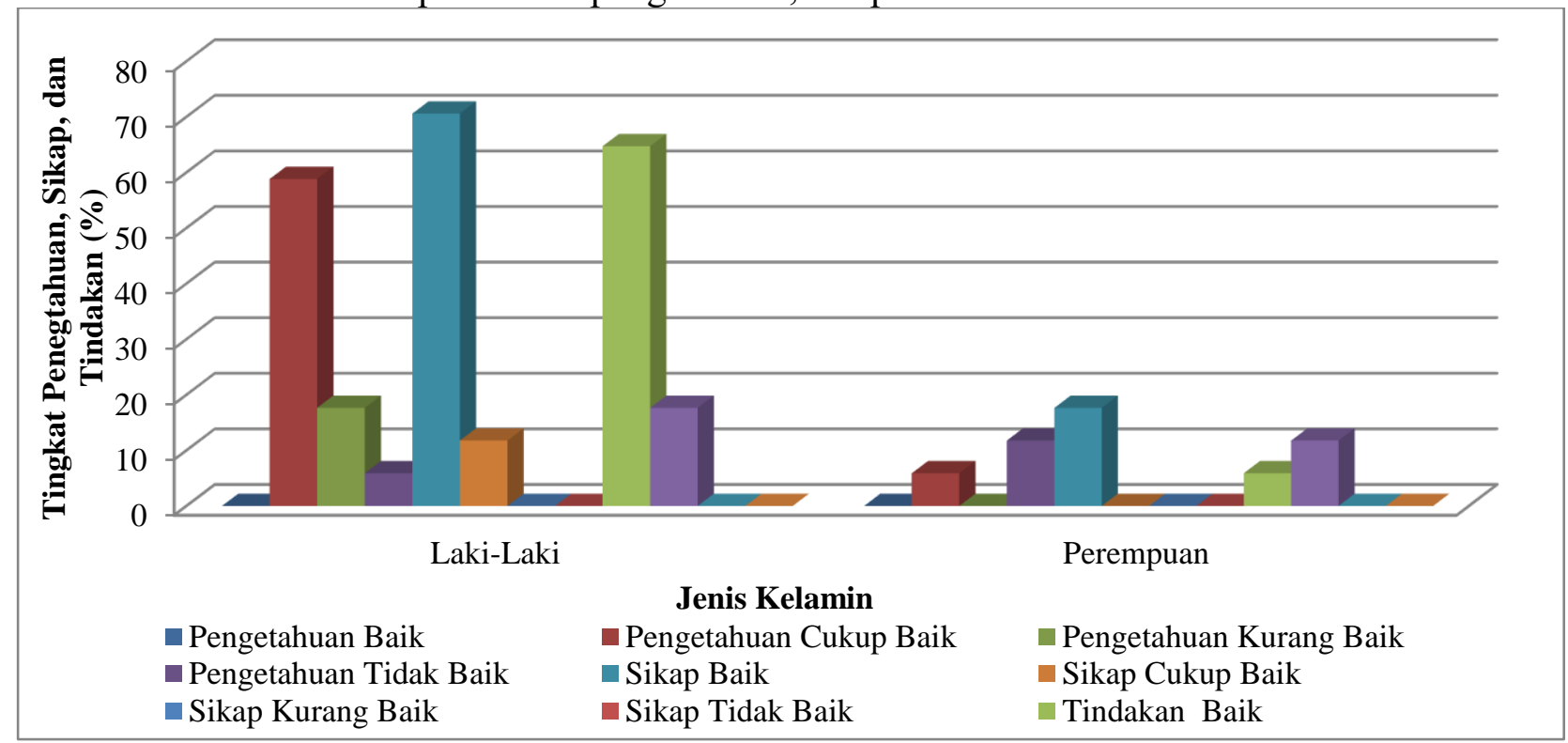

Gambar 2. Grafik persentase pengetahuan, sikap dan tindakan berdasarkan jenis kelamin 
GAMBARAN TINGKAT PENGETAHUAN, SIKAP DAN TINDAKAN PASIEN TUBERKULOSIS TERHADAP KEJADIAN TB PARU DI PUSKESMAS MEDAN AREA SELATAN

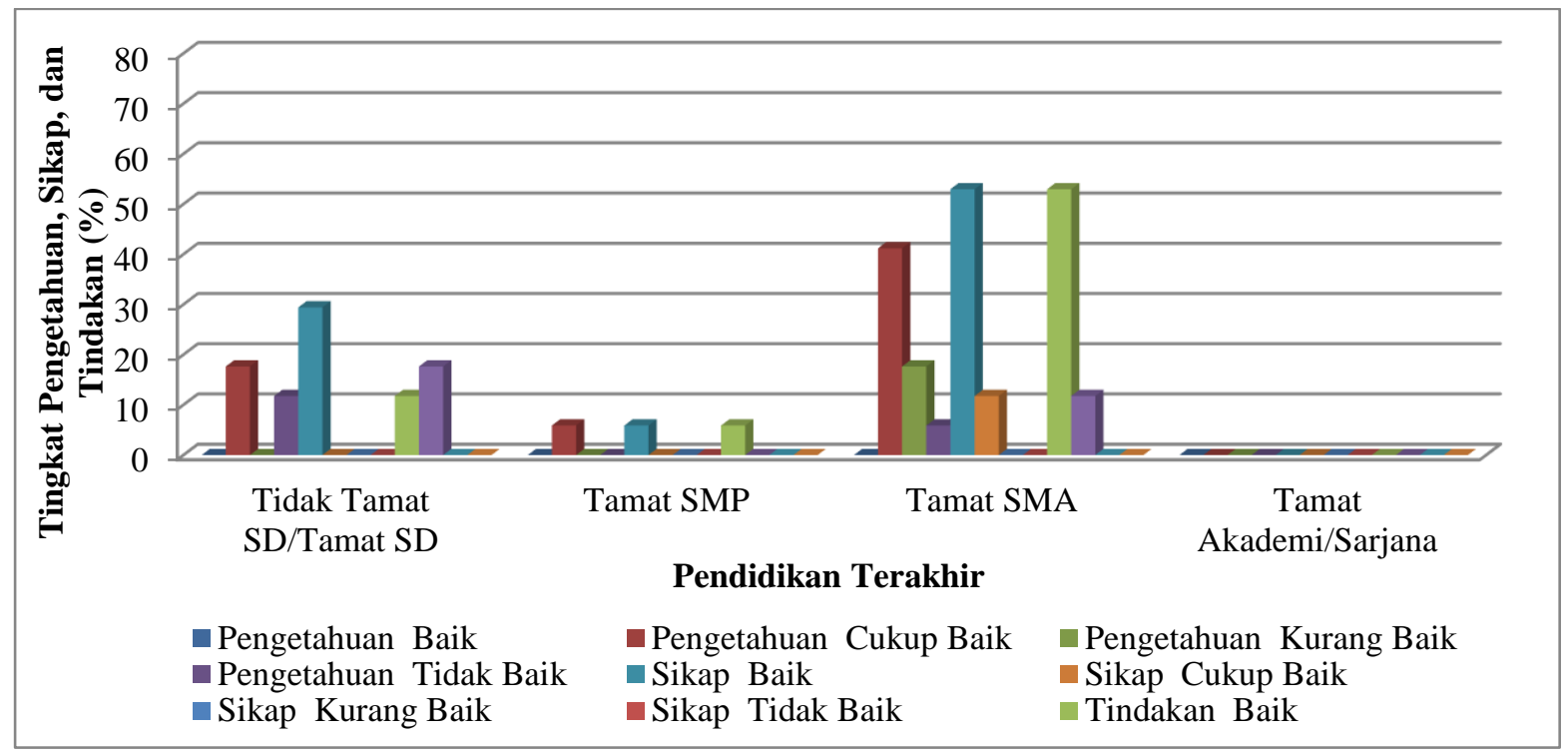

Gambar 3. Grafik persentase pengetahuan, sikap dan tindakan berdasarkan pendidikan terakhir

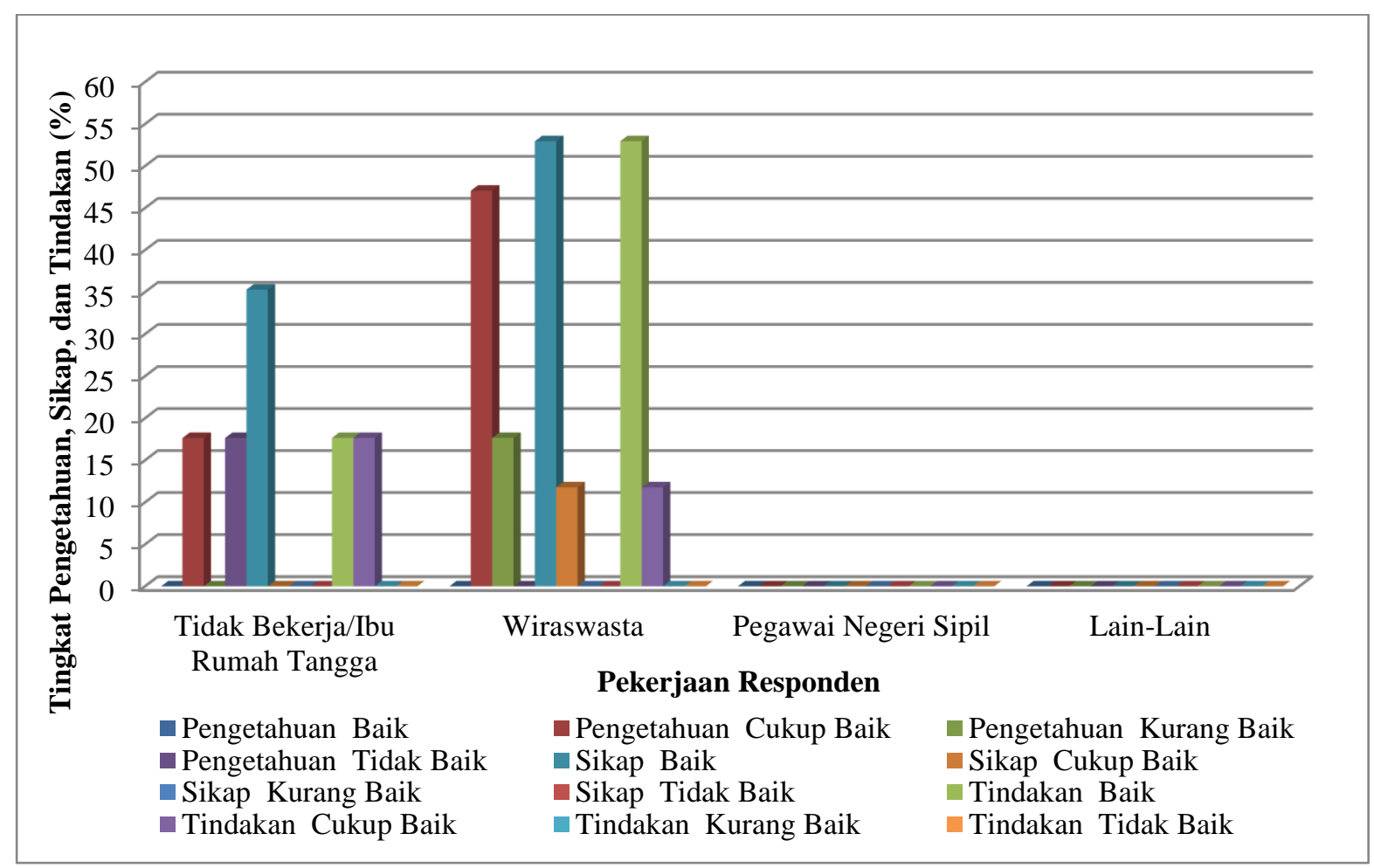

Gambar 4. Grafik persentase pengetahuan, sikap dan tindakan berdasarkan pekerjaan 
GAMBARAN TINGKAT PENGETAHUAN, SIKAP DAN TINDAKAN PASIEN TUBERKULOSIS TERHADAP KEJADIAN TB PARU DI PUSKESMAS MEDAN AREA SELATAN

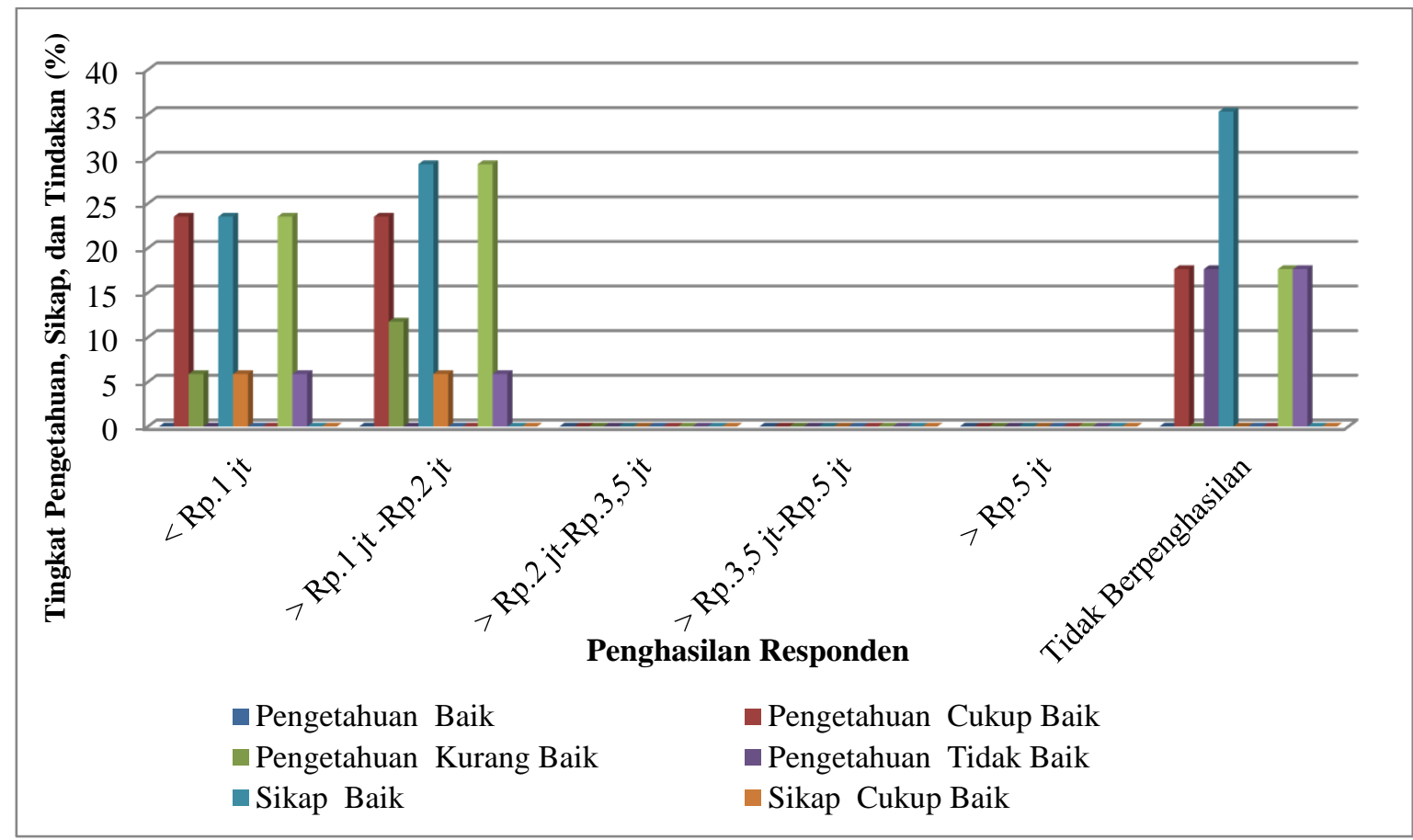

Gambar 5. Grafik persentase pengetahuan, sikap dan tindakan berdasarkan penghasilan

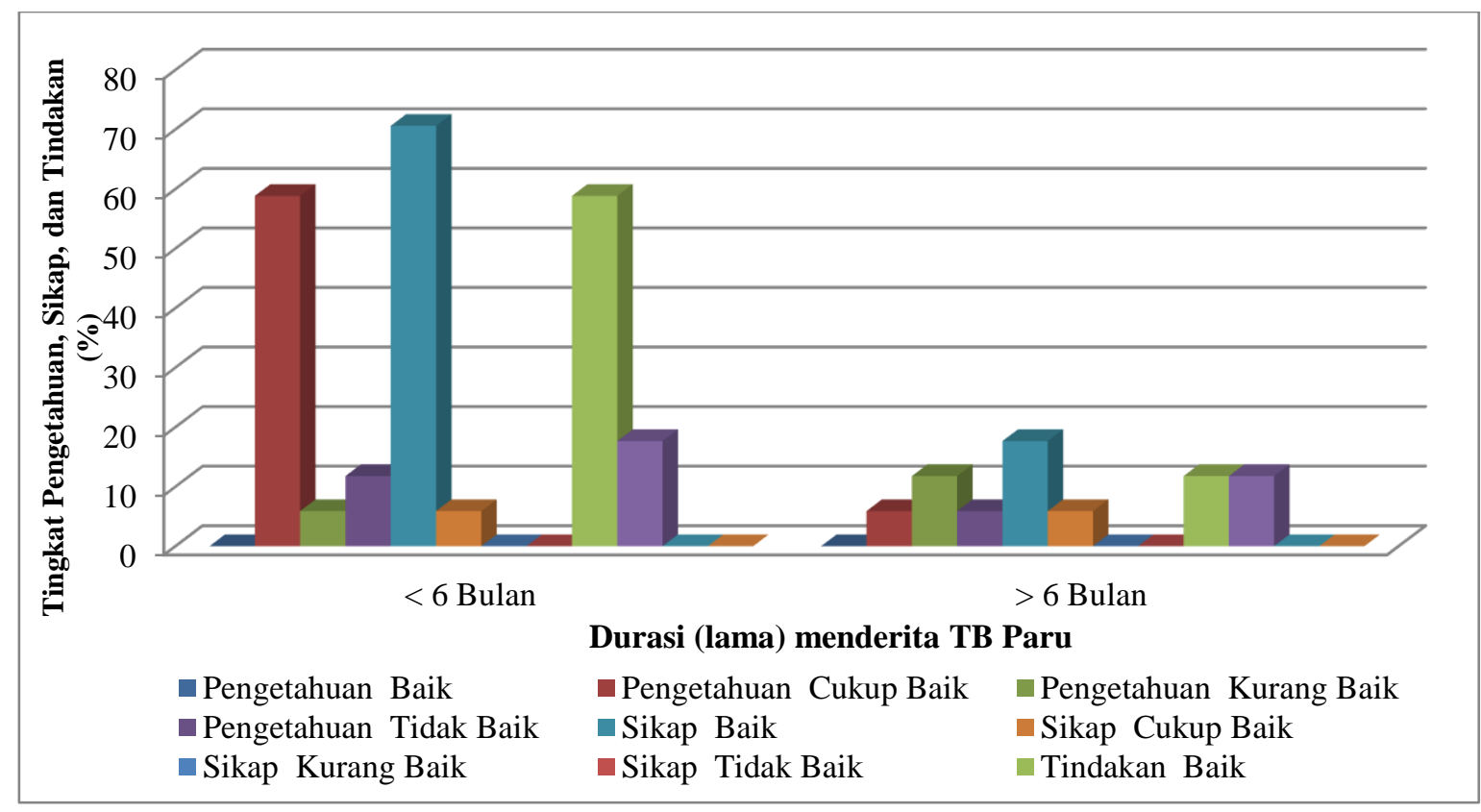

Gambar 6. Grafik persentase pengetahuan, sikap dan tindakan berdasarkan lama menderita TB 
GAMBARAN TINGKAT PENGETAHUAN, SIKAP DAN TINDAKAN PASIEN TUBERKULOSIS TERHADAP KEJADIAN TB PARU DI PUSKESMAS MEDAN AREA SELATAN

Berdasarkan Gambar 3 diketahui bahwa pengetahuan, sikap, dan tindakan responden pada tingkat pendidikan terakhir tamat SMA yang paling banyak secara berturut-turut adalah kategori cukup baik sebesar $41,18 \%$ untuk pengetahuan; sikap dengan kategori baik sebesar $52,94 \%$, dan tindakan dengan kategori baik sebesar 52,94\%.

Berdasarkan Gambar 4 diketahui bahwa pengetahuan, sikap, dan tindakan responden pada pekerjaan wiraswasta yang paling banyak secara berturut-turut adalah kategori cukup baik sebesar 47,06\% untuk pengetahuan; sikap dengan kategori baik sebesar 52,94\%, dan tindakan dengan kategori baik sebesar $52,94 \%$.

Berdasarkan Gambar 5 diketahui bahwa pengetahuan responden pada penghasilan < Rp.1.000.000 dan $>$ Rp.1.000.000-Rp.2.000.000 yang paling banyak secara berturut-turut adalah kategori cukup baik sebesar 23,53\%; sikap responden pada tidak berpenghasilan yang paling banyak dengan kategori baik sebesar 35,29\% dan tindakan responden pada penghasilan >Rp.1.000.000Rp.2.000.000 yang paling banyak dengan kategori baik sebesar 29,41\%.

Berdasarkan Gambar 6 diketahui bahwa pengetahuan, sikap, dan tindakan responden pada lama menderita $\mathrm{TB}<6$ bulan yang paling banyak secara berturutturut adalah kategori cukup baik sebesar $58,82 \%$ untuk pengetahuan; sikap dengan kategori baik sebesar 70,59\%, dan tindakan dengan kategori baik sebesar $58,82 \%$.

\section{Pembahasan}

Karakteristik responden berdasarkan usia yang paling banyak pada penelitian ini adalah berada pada usia $\geq 18-65$. Hal ini sejalan dengan penelitian sebelumnya yang dilakukan di Puskesmas Lidah Kulon Surabaya didapatkan bahwa usia 15-44 tahun yaitu sebanyak 25 orang $(58,1 \%)$, usia $\geq 65$ tahun sebanyak 18 orang $(41,9 \%)$. Usia dewasa merupakan kategori usia produktif, hal ini dikarenakan pada usia produktif terdapat kecenderungan untuk banyak melakukan interaksi dan memiliki mobilitas yang tinggi di luar rumah sehingga lebih rentan untuk tertular penyakit TB (Mitha P, 2012). Karakteristik responden berdasarkan jenis kelamin yang paling banyak adalah lakilaki. Hal ini sejalan dengan penelitian sebelumnya yang dilakukan di Rw 04 Kelurahan Lagoa Jakarta Utara didapatkan bahwa jenis kelamin responden terbanyak adalah pada laki-laki yaitu sebanyak 40 orang $(66,7 \%)$ dan perempuan sebanyak 20 orang $(33,3 \%)$. Laki-laki lebih tinggi dikarenakan lebih mudah terpapar penyakit akibat penurunan sistem imun seperti TB paru akibat kebiasaan laki-laki yang suka mengkonsumsi alkohol, kebiasaan merokok, kerja berat serta istirahat yang kurang (Astuti S, 2013).

Berdasarkan hasil penelitian yang telah dilakukan didapatkan bahwa karakteristik responden berdasarkan pendidikan terakhir yang paling banyak adalah SMA. Hal ini tidak sejalan dengan penelitian sebelumnya, karena semakin tinggi pendidikan seseorang, semakin banyak pengetahuannya. Pada penelitian ini tingkat pendidikan SMA yang lebih banyak terkena penyakit TB paru, hal ini dipengaruhi oleh beberapa faktor yaitu salah satunya adalah berdasarkan pekerjaan pasien TB paru yang pekerjaannya melakukan kontak dengan banyak orang. Karakteristik responden berdasarkan pekerjaan dan penghasilan yang paling banyak adalah pekerjaan wiraswasta dengan penghasilan yang paling banyak >Rp.1.000.000Rp.2.000.000 dan tidak berpenghasilan, hal ini sejalan dengan penelitian sebelumnya yang dilakukan di Puskesmas Sidomulyo Kota Pekanbaru didapatkan karakteristik pekerjaan responden yang paling banyak adalah wiraswasta yang berjumlah 25 orang $(57,1 \%)$. Pada 
GAMBARAN TINGKAT PENGETAHUAN, SIKAP DAN TINDAKAN PASIEN TUBERKULOSIS TERHADAP KEJADIAN TB PARU DI PUSKESMAS MEDAN AREA SELATAN

dasarnya bekerja sebagai wiraswasta seperti berdagang, memiliki resiko lebih rentan tertular dengan penderita TB paru dikarenakan pekerja melakukan kontak dengan banyak orang dan semakin tinggi penghasilan seseorang maka tingkat kepeduliannya untuk kesehatan semakin tinggi pula (Dewita R, 2017).

Berdasarkan hasil penelitian yang telah dilakukan didapatkan bahwa karakteristik responden berdasarkan lama menderita TB yang paling banyak adalah $<6$ bulan, hal ini sejalan dengan penelitian sebelumnya yang dilakukan di Puskesmas Sidomulyo Kota Pekanbaru didapatkan lama pengobatan yang dijalani responden adalah selama 6 bulan pada 4 orang $(19,05 \%), 5$ bulan pada 2 orang $(9,55 \%), 4$ bulan pada 4 orang $(19,05 \%), 3$ bulan pada 6 orang $(28,5 \%)$, dan diikuti selama 2 bulan pada 4 orang $(19,05 \%)$ serta 1 bulan sebanyak 1 orang $(4,8 \%)$. Hal ini dikarenakan pasien yang baru menderita TB ingin cepat sembuh dan pasien pun lebih rutin melakukan pengobatan daripada pasien yang lama menderita TB (Dewita R, 2017).

Pengetahuan adalah hasil terhadap suatu objek setelah melakukan penginderaan. Pengetahuan dapat dipengaruhi oleh faktor internal dan eksternal, dimana faktor internal terdiri dari pendidikan, pekerjaan dan umur. Sedangkan faktor eksternal dipengaruhi oleh lingkungan dan sosial budaya. Pengetahuan disini diukur melalui pemberian kuesioner dengan karakteristik responden berdasarkan usia, jenis kelamin, pendidikan terakhir, pekerjaan, penghasilan dan lama menderita TB yang berisi pertanyaan tentang penularan, penyebab, pencegahan dan pengobatan TB. Pada pengetahuan responden juga dapat dipengaruhi oleh usia semakin tua usia seseorang maka daya tangkapnya akan semakin rendah sehingga pengetahuan yang diperoleh akan semakin buruk.

Pengetahuan juga dapat dipengaruhi

oleh tingkat pendidikan, semakin tinggi tingkat pendidikan seseorang akan semakin baik tingkat pengetahuannya (Notoatmodjo, 2010). Hal ini tidak sejalan dengan penelitian ini, karena pada penelitian ini tingkat pendidikan SMA yang lebih banyak terkena penyakit TB paru, hal ini dipengaruhi oleh beberapa faktor yaitu salah satunya adalah berdasarkan pekerjaan pasien TB paru yang pekerjaannya melakukan kontak dengan banyak orang. Pengetahuan yang baik sangat diharapkan dalam mencegah dan menanggulangi penyakit TB paru. Tingkat pengetahuan yang rendah dalam upaya mencegah dan menanggulangi penyakit TB paru dapat menjadi faktor resiko terjadinya penularan $\mathrm{TB}$ paru. Rendahnya tingkat pendidikan akan berpengaruh pada pemahaman mengenai penyakit TB paru. Sedangkan pasien dengan tingkat pendidikan yang lebih tinggi akan mempengaruhi perilakunya dalam upaya pengendalian penularan penyakit TB paru. Gambaran pengetahuan pasien kejadian TB paru pada penelitian ini berada dalam kategori yang cukup baik, hal ini terjadi karena minimnya informasi serta tidak adekuatnya informasi yang didapatkan dan diterima oleh responden.

Sikap merupakan suatu predisposisi yang digunakan untuk merespon suatu objek baik secara positif atau negatif pada situasi, maupun konsep dan orang. Sikap yang berorientasi pada respon adalah perasaan mendukung atau tidak mendukung serta kesiapan dalam bereaksi terhadap suatu objek. Sikap yang terbentuk bergantung pada persepsi seseorang dalam mengintrepretasikan sesuatu dan bertindak atas dasar hasil intrepretasi yang diciptakannya. Salah satu faktor yang mempengaruhi dalam pembentukan sikap adalah pengetahuan yang dimiliki seseorang. Sikap disini diukur melalui pemberian kuesioner yang berisi pertanyaan tentang penularan, penyebab, pencegahan dan pengobatan TB Semakin tinggi tingkat pengetahuan yang dimiliki seseorang akan memberi kontribusi pada terbentuknya sikap yang baik. Sehingga dapat disimpulkan bahwa seseorang dapat memperoleh sikap yang baik 
GAMBARAN TINGKAT PENGETAHUAN, SIKAP DAN TINDAKAN PASIEN TUBERKULOSIS TERHADAP KEJADIAN TB PARU DI PUSKESMAS MEDAN AREA SELATAN

terhadap upaya pengendalian penyakit TB jika pengetahuan yang diperolehnya juga baik dan memadai. Suatu sikap belum tentu otomatis terwujud dalam suatu perilaku yang terlihat melalui tindakan.

Perilaku yang terwujud dalam bentuk tindakan sangat dipengaruhi oleh tingkat pengetahuan dan sikap dari pasien TB paru. Tindakan disini diukur melalui pemberian kuesioner yang berisi pertanyaan tentang penularan, penyebab, pencegahan dan pengobatan TB. Tindakan pasien seperti melakukan pemeriksaan dahak, menutup mulut ketika batuk, meningkatkan daya tahan tubuh, tidak membuang dahak disembarang tempat, meminum obat TB secara rutin merupakan tindakan yang tepat dilakukan oleh pasien untuk mencegah penularan infeksi lebih luas.

\section{KESIMPULAN}

Tingkat pengetahuan yang cukup baik dari pasien terhadap penularan, penyebab, pencegahan dan pengobatan TB paru di Puskesmas Medan Area Selatan diimplementasikan dengan sikap dan tindakan baik dari pasien.

\section{DAFTAR PUSTAKA}

Astuti S., 2013. Hubungan Tingkat Pengetahuan Dan Sikap Masyarakat Terhadap Upaya Pencegahan Penyakit Tuberkulosis Di Rw 04 Kelurahan Lagoa Jakarta Utara Tahun 2013. Skripsi. Fakultas Kedokteran Dan Ilmu Kesehatan Universitas Islam Negeri Syarif Hidayatullah Jakarta.

Depkes RI., 2018. Pusat Data Informasi Kementerian Kesehatan Republik Indonesia. Jakarta: Departemen Kesehatan.

Depkes RI., 2008. Pedoman Nasional Pengendalian Tuberkulosis. Jakarta: Kementerian Kesehatan
Republik Indonesia Direktorat Jenderal Pengendalian Penyakit dan Penyehatan Lingkungan.

Dewita, R., Hajar, S dan Suyanto., 2017. Gambaran Pengetahuan Dan Sikap Pasien TB Paru Terhadap Upaya Pengendalian TB Di Puskesmas Sidomulyo Kota Pekanbaru. Jurnal Online Mahasiswa Fakultas Kedokteran.

Dinkes Kota Medan., 2016. Profil Kesehatan 2016. Medan: Dinas Kesehatan Kota Medan.

Kemenkes RI., 2017. Profil Kesehatan Indonesia 2016. Jakarta: Menteri Kesehatan Republik Indonesia.

Loscalzo, J., 2014. Harrison Pulmonologi dan Penyakit Kritis. Edisi 2. Jakarta: $\quad$ EGC.

Loscalzo, J., 2010. Pulmonary and Critical Care Medicine. Newyork: Mc Grand Hill Medical.

Mitha P., 2012. Hubungan Pengetahuan Dan Sikap Penderita TB Paru Dengan Kepatuhan Minum Obat Anti Tuberkulosis Di Puskesmas Lidah Kulon Surabaya. Skripsi. Fakultas Kesehatan Masyarakat Universitas Airlangga.

Notoatmodjo, S., 2010. Promosi Kesehatan dan Perilaku Kesehatan. Jakarta: Rineka Cipta.

Notoatmodjo, S., 2012. Metodologi Penelitian Kesehatan. Jakarta: Rineka Cipta.

Paul, et all., Knowledge and attitude of key community members towards tuberculosis : mixed method study from BRAC TB control areas in Bangladesh. BMC Public Health.

Jurnal Kesehatan Published By Poltekkes Ternate, 12, (2), 2019, Pages, 238 - 251. 
GAMBARAN TINGKAT PENGETAHUAN, SIKAP DAN TINDAKAN PASIEN TUBERKULOSIS TERHADAP KEJADIAN TB PARU DI PUSKESMAS MEDAN AREA SELATAN

$2015 ; p .5$.

Sugiyono., 2013. Metode Penelitian

Pendidikan Pendekatan

Kuantitatif, Kualitatif, dan R\&D.

Bandung: Alfabeta.

Wahyudi, E., 2006. Hubungan Antara Pengetahuan Tentang TB Paru Dengan Tindakan Pencegahan Penularan Pada Keluarga Penderita TB Paru Di Wilayah Kerja Puskesmas Ponorogo Utara.

Skripsi. Universitas Airlangga. 